\title{
Inheritance of Calcium Use Efficiency in Tomatoes Grown under Low-calcium Stress
}

\author{
Yin-ming Li'ind W.H. Gabelman \\ Department of Horticulture, University of Wisconsin, Madison, WI 53706
}

Additional index words. nutrient efficiency, tomato breeding, Lycopersicon esculentum

\begin{abstract}
Sixty highly homozygous tomato (Lycopersicon esculentum Mill.) strains, some selected from previous studies and some collected from known low-Ca regions, were screened under a low-Ca culture system (10 mg of Ca per plant). Four strains were selected to represent the extremes for $\mathrm{Ca}$ efficiency and used as parents to create a series of $F_{1}, F_{2}$, and backcross generations for inheritance studies of Ca use under low-Ca stress. Based on total plant dry weight, additive and dominance gene effects were most important for the efficiency of Ca use. Maternal control of efficiency in Ca use was not observed. Estimates of broad-sense heritability ranged from $63 \%$ to $79 \%$ for total play dry weight. Narrow sense heritabilities, determined in only two of the families, were $47 \%$ to $49 \$$ and $68 \%$ to $75 \%$.
\end{abstract}

The classification of plant species as calcifuge and calcicole plants by Clarkson (1965) showed clearly that plant species have evolved in different ways based on genetic changes and on the probable selection pressure associated with high and low $\mathrm{Ca}$ in their environments. Phenotypic differences in Ca efficiency have been reported to be associated with genotypic differences in $\mathrm{Ca}$ uptake, transport, and distribution (Marschner, 1986).

The systematic isolation and characterization of differences in Ca use among strains of tomato by Giordano et al. (1982), using solution culture, was the first study of naturally occurring phenotypic variance with Lycopersicon esculentum. Their data indicated that difference; in $\mathrm{Ca}$ efficiency were associated with differences in uptake, controlled by the genotype of the plant top, and in Ca use.

Subsequently, Behling (1987) demonstrated that the Mg ion concentration in Giordano's low-Ca solution interfered with $\mathrm{Ca}$ uptake; by lowering the $\mathrm{Mg}^{2+}$ from $48 \mathrm{ppm}$ to $24 \mathrm{ppm}$, the entire $10 \mathrm{mg} \mathrm{Ca}$ in solution was removed by the plant. Differences between strains were associated with transport and use of $\mathrm{Ca}$.

The many Ca-associated disorders among agricultural crops, e.g., tipburn in cabbage and lettuce, blossom-end rot in tomato, and bitter pit in apple, are primarily in leaves and fruit with low transpiration. A recent report (Banuelos et al., 1987) indicated that the basipetal transport of IAA contributes to the acropetal transport of $\mathrm{Ca}$ into low-transpiring tissues, such as tomato fruit. Their latter research (Banuelos et al., 1988) also showed that, in the low-transpiring leaves of lettuce the basipetal auxin transport favors the acropetal transport of Ca. Efficient strains of tomato transported ${ }^{45} \mathrm{Ca}$ into the leaf lamina in the absence of any significant transpiration, while inefficient strains did not (Behling, 1987). Thus, the development of a seedling test that identifies efficiency in Ca use, particularly if it reflects movement of $\mathrm{Ca}$ into the leaf lamina in the absence of transpiration, could have wide application in breeding for tolerance to these many Ca-deficiency syndromes.

The purpose of our study was to investigate the efficiency of $\mathrm{Ca}$ use in tomato strains using Behling's low-Ca solution modified for Mg. Our primary objective was to use strains with

Received for publication 8 May 1989. The cost of publishing this paper was defrayed in part by the payment of page charges. Under postal regulations, this paper therefore must be hereby marked advertisement solely to indicate this fact.

'Present address: Dept. of Horticulture, Michigan State Univ., East Lansing, MI 48823.

${ }^{2}$ Professor of Horticulture. maximum differences in Ca use efficiency to study the inheritance of efficiency under low-Ca stress.

\section{Materials and Methods}

Sixty homozygous tomato strains, including some from known low-Ca regions previously selected by Giordano et al. (1982), were evaluated using a low-Ca nutrient solution. Seeds were germinated in disposable growth pouches (Northrup-King) with $25 \mathrm{ml}$ of a half-normal concentration Hoagland solution. The growth pouch medium was maintained at the proper moisture level by addition of distilled water only. After 11 to 12 days, seedlings were transplanted singly into plastic pots containing 1.8 liter of a nutrient solution composed of $2.5 \mathrm{mM}\left(\mathrm{KNO}_{3}\right), 5.0 \mathrm{mM}\left(\mathrm{NaNO}_{3}\right), 0.5 \mathrm{~mm}$ $\left(\mathrm{KH}_{2} \mathrm{PO}_{4}\right), 1.0 \mathrm{~mm}\left(\mathrm{MgSO}_{4} \cdot 7 \mathrm{H}_{2} \mathrm{O}\right), 25 \mu \mathrm{M}\left(\mathrm{H}_{3} \mathrm{~B} \mathrm{O}_{3}\right), 5 \mu \mathrm{M}$ $\left(\mathrm{MnSO}_{4} \cdot \mathrm{H}_{2} \mathrm{O}\right), 2 \mu \mathrm{M}\left(\mathrm{ZnSO}_{4} \cdot 7 \mathrm{H}_{2} \mathrm{O}\right), 0.5 \mu \mathrm{M}\left(\mathrm{CUSO}_{4} \cdot 5 \mathrm{H}_{2} \mathrm{O}\right)$, and $0.015 \mu \mathrm{M}\left(\mathrm{NH}_{4}\right)_{6} \mathrm{Mo}_{7} \mathrm{O}_{24} \cdot 4 \mathrm{H}_{2} \mathrm{O}$. Iron was supplemented as $\mathrm{Fe}-$ EDTA at an initial concentration of $0.04 \mathrm{~mm}$. Initial $\mathrm{Ca}$ concentrations were adjusted to $5 \mathrm{mg} \cdot \mathrm{kg}^{-1}$ with the addition of $\mathrm{CaCl}_{2} \cdot 2 \mathrm{H}_{2} \mathrm{O}$. Distilled water was added as needed throughout the experiment to maintain $\approx 1.8$ liter of solution. Initially the solution was adjusted to $\mathrm{pH} 5.5$ with $0.01 \mathrm{~N} \mathrm{NaOH}$. Magnesium was adjusted to 24 $\mathrm{mg} \cdot \mathrm{kg}^{-1}$ (Behling, 1987).

Plants were grown for 28 to 30 days, at which time nearly all the available $\mathrm{Ca}$ had been removed from solution and growth had almost stopped. Temperatures in the growth room were maintained at $\approx 32$ to $35 \mathrm{C}$ during the light period and 21 to $25 \mathrm{C}$ during the dark period. A light intensity of $200-300 \mu \mathrm{mol} \cdot \mathrm{s}^{-1} \cdot \mathrm{m}^{-2}$ at the top of the canopy was provided by cool-white fluorescent lamps for $16 \mathrm{hr}$ in each 24-hr cycle. Calcium analyses were made with a Varian atomic absorption spectrophotometer model Spectra AA-20 (Mulgrave, Victoria, Australia).

Strains were characterized as Ca-efficient (E) and Ca-inefficient (I) in the screening phase based on 1) the amount of total plant dry matter produced, 2) the plant Calcium Efficiency Ratio $(\mathrm{CaER}=\mathrm{mg}$ of total plant dry weight $/ \mathrm{mg}$ of $\mathrm{Ca}$ in total plant $)$, and 3) calcium deficiency symptoms- that is, reduction in plant size, distortion of leaves, and death of terminal buds.

Fifteen tomato strains were selected from preliminary trials and evaluated simultaneously in a replicated test. In addition to the low-Ca stress level (10 mg Ca/plant), plants of these strains were also grown at $400 \mathrm{mg} \mathrm{Ca} /$ plant. The adequate $\mathrm{Ca}$ level was included to observe if differences among tomato strains existed when $\mathrm{Ca}$ was not limiting. Strains that grew poorly at the adequate $\mathrm{Ca}$ level might be inefficient in dry matter accumulation, regardless of $\mathrm{Ca}$ availability, and such strains were 
not selected for further inheritance study. Seven of the 15 strains were chosen for a final evaluation using the two levels of $\mathrm{Ca}$. A randomized complete block design was used with four replications of each strain in all screening experiments. Four strains were selected from the final screening experiment to represent the extremes for $\mathrm{Ca}$ efficiency.

A preliminary study was made to determine if maternal differences were important for $\mathrm{Ca}$ use efficiency. A diallel cross of four parent strains resulted in 16 entries of $F_{1}$, reciprocal $F_{1}$, and selfed progeny that were grown simultaneously under low$\mathrm{Ca}$ conditions. A completely randomized block design was used with four replications of each entry. Analyses were made on total plant dry weight and CaER values.

A family. was composed of six generations, as follows: $P_{1}$ and $\mathrm{P}_{2}$ (parent strains), $\mathrm{F}_{1} \mathrm{~s}\left(\mathrm{P}_{1} \times \mathrm{P}_{2}\right.$ and $\left.\mathrm{P}_{2} \times \mathrm{P}_{1}\right), \mathrm{F}_{2}\left(\mathrm{~F}_{1}\right.$-selfed $)$, $\mathrm{BC}_{1} \mathrm{P}_{1}\left(\mathrm{P}_{1} \times \mathrm{F}_{1}\right)$, and $\mathrm{BC}_{1} \mathrm{P}_{2}\left(\mathrm{P}_{2} \times \mathrm{F}_{1}\right)$. All six possible families originating from crosses among the two efficient and the two inefficient strains were grown in six separate generation means experiments. In evaluating each family, 12 plants of each parent, eight of each reciprocal $F_{1}, 40$ of each backcross, and 40 $\mathrm{F}_{2}$ plants from each reciprocal $\mathrm{F}_{1}$ hybrid were grown. Because total plant dry weights were highly correlated with CaER values and $\mathrm{Ca}$ deficiency symptoms at the low-Ca stress level, only total plant dry weight data are presented. Generation mean analyses were calculated by using the method of Mather and Jinks (1977) and genetic effects were estimated. Environmental and genetic variances for total plant dry weight of segregating populations were determined by the methods of Voigt et al. (1966), and broad-sense heritabilities estimated in each family.

Parent-offspring regression was used to estimate narrow-sense heritability only. Two of the four families, derived from crosses between efficient and inefficient strains $(\mathrm{E} \times \mathrm{I})$, were used to develop the required later generation. Before harvest, $20 \mathrm{~F}_{2}$ plants, $20 \mathrm{BC}_{1} \mathrm{P}_{1}$, and $20 \mathrm{BC}_{1} \mathrm{P}_{2}$ plants in each of the two families were chosen randomly. Fresh weights were determined, and the selected plants returned to the growth medium containing a normal Hoagland's solution to permit recovery from the effects of $\mathrm{Ca}$ deficiency. After 7 to 10 days of recovery, the plants were transferred to the greenhouse and transplanted to 1.8-liter (9-inch) pots containing greenhouse soil. $\mathrm{F}_{3}, \mathrm{BC}_{1} \mathrm{P}_{1} \mathrm{~S}_{1}$, and $\mathrm{BC}_{1} \mathrm{PZSI}$ seeds were obtained and tested in separate experiments. Each experiment consisted of eight plants of each parent, $\mathrm{P}_{1}$ and $\mathrm{P}_{2}$, and five plants of each derived $\mathrm{F}_{3}, \mathrm{BCP}_{1} \mathrm{~S}_{1}$, and $\mathrm{BCP}_{2} \mathrm{~S}_{1}$ progeny. All five members of each $\mathrm{F}_{3}, \mathrm{BC}_{1} \mathrm{P}_{1} \mathrm{~S}_{1}$, and $\mathrm{BC}_{1} \mathrm{P}_{2} \mathrm{~S}_{1}$ progenies traced back either to a single $\mathrm{F}_{2}$ or a single backcross plant, respectively. Thus, each of the two experiments included $100 \mathrm{~F}_{3}$ plants, $100 \mathrm{BC}_{1} \mathrm{P}_{1} \mathrm{~S}_{1}$, and $100 \mathrm{BC}_{1} \mathrm{P}_{2} \mathrm{~S}_{1}$ plants.

Progenies of selected plants $\left(\mathrm{F}_{3}, \mathrm{BC}_{1} \mathrm{P}_{1} \mathrm{~S}_{1}\right.$, and $\left.\mathrm{BC}_{1} \mathrm{P}_{2} \mathrm{~S}_{1}\right)$ were regressed on their respective parents $\left(\mathrm{F}_{2}, \mathrm{BC}_{1} \mathrm{P}_{1}\right.$, and $\left.\mathrm{BC}_{1} \mathrm{P}_{2}\right)$. Because only fresh weights of selected plants were available, the dry weight of parental plants had to be estimated by other means. A basic linear regression, based on a procedure outlined by Fawole et al. (1982), was used. Narrow-sense heritability estimates for total plant dry weight and standard error of the heritability estimates were calculated according to the methods described by Smith and Kinman (1965), and Hallauer and Miranda (1981).

\section{Results}

A wide range in efficiency in Ca use was found among 60 selected strains tested (Li, 1989). In the final rescreening experiment, significant differences among strains were observed for total plant dry weight. Efficient strains 113 and 99 and inefficient strains 67 and 118 were chosen to represent extremes in $\mathrm{Ca}$ use for inheritance studies. There were no significant differences in total plant dry weight among these four strains when grown under the adequate $\mathrm{Ca}$ level (Table 1). All, or nearly all, of the $\mathrm{Ca}$ in the low-Ca solution was taken up by the plants. Root dry weight of efficient and inefficient strains did not differ. However, differences in shoot dry weight between these strains were large and appeared to be the major reflection of differences in $\mathrm{Ca}$ efficiency.

In the preliminary inheritance study, four parent strains and all possible combinations of reciprocal $F_{1}$ progenies were tested under low-Ca stress. Comparisons of total plant dry weight and CaER between reciprocal $\mathrm{F}_{1} \mathrm{~s}$ were nonsignificant in all crosses

Table 1. Mean total plant dry weight of seven tomato strains grown under low-Ca stress and at adequate $\mathrm{Ca}$ level in the final screening experiment.

\begin{tabular}{|c|c|c|c|}
\hline \multirow[b]{2}{*}{ Strain } & \multicolumn{2}{|c|}{ Dry wt $(g)^{z, y}$} & \multirow{2}{*}{$\begin{array}{l}\text { Ca efficiency } \\
\text { classification }^{x}\end{array}$} \\
\hline & Low $\mathrm{Ca}(10 \mathrm{mg})$ & High $\mathrm{Ca}(400 \mathrm{mg})$ & \\
\hline 113 & $4.46 \mathrm{a}$ & $6.25 b^{x}$ & $E$ \\
\hline 99 & $4.33 \mathrm{a}$ & $6.39 \mathrm{~b}$ & $\mathrm{E}$ \\
\hline 100 & $4.23 \mathrm{a}$ & $7.34 \mathrm{a}$ & \\
\hline 35 & $4.20 \mathrm{a}$ & $7.01 \mathrm{ab}$ & \\
\hline 67 & $3.42 \mathrm{~b}$ & $6.47 \mathrm{~b}$ & I \\
\hline 118 & $3.39 \mathrm{~b}$ & $6.20 \mathrm{bc}$ & I \\
\hline 186 & $3.27 \mathrm{~b}$ & $5.61 \mathrm{c}$ & \\
\hline $\mathrm{LSD}_{0.05}$ & 0.417 & 0.859 & \\
\hline
\end{tabular}

${ }^{2}$ Mean of four replications.

'Mean separation within columns by Fisher's protected LSD at the 5\% level.

${ }^{\mathrm{x}} \mathrm{E}=$ Ca-efficient, $\mathrm{I}=$ Ca-inefficient.

Table 2. Mean total plant dry weight and CaER of the four parents and their six reciprocal $F_{1}$ hybrids grown under low-Ca stress (10 $\mathrm{mg} \mathrm{Ca} /$ plant) in a diallel experiment.

\begin{tabular}{lll}
\hline \hline & \multicolumn{2}{c}{ Criterion $^{z, y}$} \\
\cline { 2 - 3 } Entry & $\begin{array}{c}\text { Plant dry } \\
\text { wt }(\mathrm{g})\end{array}$ & CaER \\
\hline Parents & & \\
$99(\mathrm{E}) \mathrm{y}$ & $4.22 \mathrm{a}$ & $430 \mathrm{a}$ \\
$113(\mathrm{E})$ & $4.41 \mathrm{a}$ & $449 \mathrm{a}$ \\
$67(\mathrm{I})$ & $3.35 \mathrm{~b}$ & $342 \mathrm{~b}$ \\
$118(\mathrm{I})$ & $3.23 \mathrm{~b}$ & $330 \mathrm{~b}$ \\
LSD & 0.320 & 58 \\
Crosses & & \\
$99 \times 113$ & 4.43 & 451 \\
$113 \times 99$ & $4.39 \mathrm{NS}$ & $448 \mathrm{NS}$ \\
$99 \times 67$ & 4.11 & 423 \\
$67 \times 99$ & $4.02 \mathrm{NS}$ & $414 \mathrm{NS}$ \\
$99 \times 118$ & 3.93 & 401 \\
$118 \times 99$ & $4.16 \mathrm{NS}$ & $424 \mathrm{NS}$ \\
$113 \times 67$ & 4.02 & 441 \\
$67 \times 113$ & $4.06 \mathrm{NS}$ & $445 \mathrm{NS}$ \\
$113 \times 118$ & 4.35 & 444 \\
$118 \times 113$ & $4.18 \mathrm{NS}$ & $430 \mathrm{NS}$ \\
$67 \times 118$ & 3.54 & 365 \\
$118 \times 67$ & $3.45 \mathrm{NS}$ & $359 \mathrm{NS}$ \\
\hline
\end{tabular}

${ }^{2}$ Mean separation within columns by Fisher's protected LSD at the $5 \%$ level.

${ }^{y}$ Mean of four replications per entry. CaER $=m g$ of total plant dry weight $/ \mathrm{mg}$ of $\mathrm{Ca}$ in plant.

${ }^{\mathrm{x}} \mathrm{Ca}$ efficiency classification: $\mathrm{E}=\mathrm{Ca}$-efficient; $\mathrm{I}=\mathrm{Ca}$-inefficient ${ }^{\text {Ns }}$ Nonsignificant. 
Table 3. Generation means, phenotypic variances, and broad-sense heritability estimates of total plant dry weight for six families in generation mean experiments.

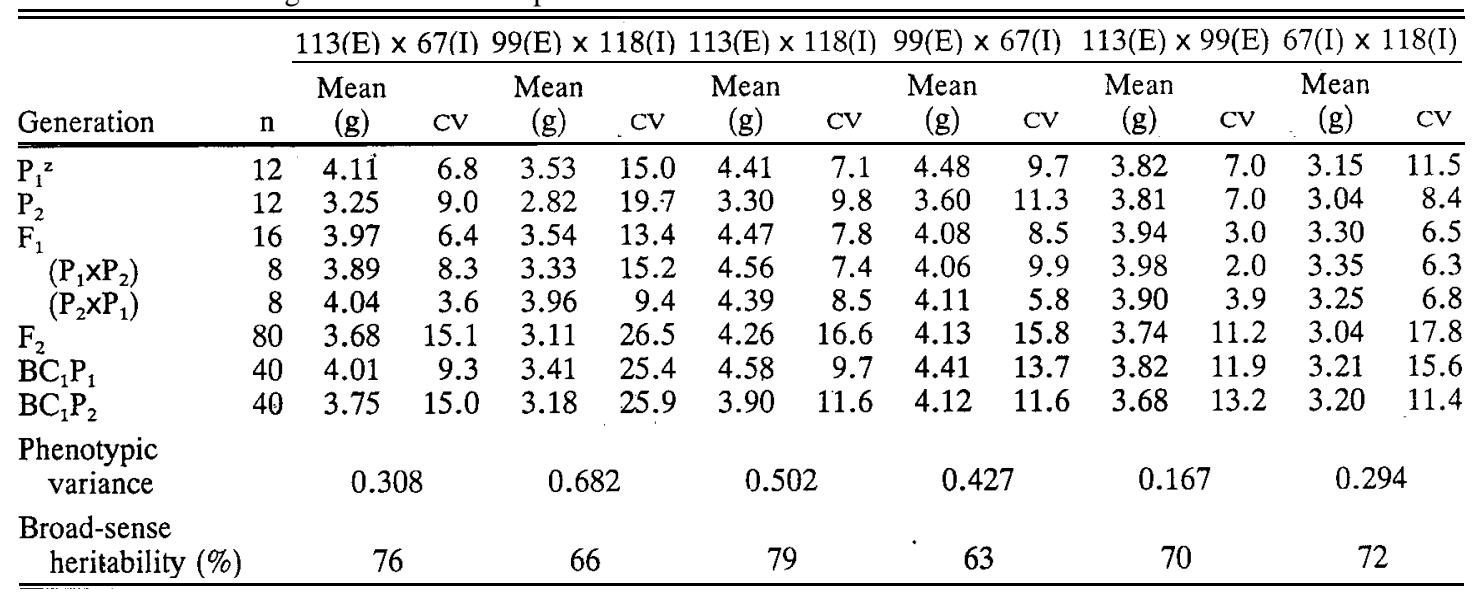

${ }^{2} \mathrm{P}_{1}$ is the first parent designated for each family; $\mathrm{P}_{2}$ is the second.

Table 4. Frequency distribution for total plant dry weight $(\mathrm{g})$ of the six derived generations in the family involving $99(\mathrm{E})$ and $67(\mathrm{I})$, grown under low-Ca stress $(10 \mathrm{mg} / \mathrm{plant})$.

\begin{tabular}{|c|c|c|c|c|c|c|c|c|c|c|c|c|c|}
\hline \multirow[b]{2}{*}{ Generation } & \multicolumn{10}{|c|}{ Number of plants per class } & \multirow[b]{2}{*}{$\mathrm{N}$} & \multirow[b]{2}{*}{ (g) } & \multirow[b]{2}{*}{$(\%)$} \\
\hline & $2.0-2.3$ & $2.4-2.7$ & $2.8-3.1$ & $3.2-3.5$ & $3.6-3.9$ & $4.0-4.3$ & $4.4-4.7$ & $4.8-5.1$ & $5.2-5.5$ & $5.6-5.9$ & & & \\
\hline$\overline{P_{1}(99 E)}$ & & & & & & 2 & & 9 & 1 & & 12 & 4.48 & 9.7 \\
\hline$P_{2}(67 \mathrm{I})$ & & 1 & 2 & 1 & 7 & 1 & & & & & 12 & 3.60 & 11.3 \\
\hline $\mathrm{F}_{1}$ & & & & $\vdots$ & 6 & 9 & 1 & & & & 16 & 4.08 & 8.5 \\
\hline & 1 & & 4 & 5 & 15 & 26 & 14 & 9 & 4 & 2 & 80 & 4.13 & 15.8 \\
\hline $\mathrm{BCP}_{1}$ & & & & 2 & 4 & 15 & 10 & 6 & 2 & 1 & 40 & 4.41 & 13.7 \\
\hline $\mathrm{BCP}_{2}$ & & & 11 & 3 & 10 & 17 & 9 & & & & 40 & 4.10 & 11.6 \\
\hline
\end{tabular}

(Table 2). Based on total plant dry weight, differences between efficient and inefficient strains were fairly consistent in all separate generation means experiments. Plant dry weight cvs of the nonsegregating $\mathrm{P}_{1}, \mathrm{P}_{2}$, and $\mathrm{F}_{1}$ generations were usually smaller than cvs of the $\mathrm{F}_{2}, \mathrm{BC}_{1} \mathrm{P}_{1}$, and $\mathrm{BC}_{1} \mathrm{P}_{2}$ segregating generations (Table $3)$. There were no differences in generation means for the progenies derived from the hybrid of strain $113(\mathrm{E}) \times 99(\mathrm{E})$ and67(I) $\times$ 118(1). Consequently, these two families were eliminated from further genetic analysis. Since results obtained from the families of the four crosses between efficient and inefficient strains (E x I) were similar, segregation data are presented (Table 4) only for one family $(99 \mathrm{E} \times 67 \mathrm{I})$. Frequency distributions and means for this family suggested additive gene effects. The $\mathrm{F}_{1}$ was intermediate compared to the two parents, the $\mathrm{BC}_{1} \mathrm{P}_{1}$ was skewed toward the $\mathrm{P}_{1}$, and the $\mathrm{BC}_{1} \mathrm{P}_{2}$ was skewed toward the $\mathrm{P}_{2}$. The $\mathrm{F}_{2}$ mean also was intermediate to the parents with individual plants distributed across and beyond the range of both parents. These results indicate the presence of transgressive segregation.

The means of six generations in each family provided estimates of various gene effects for total plant dry weight (Table 5). The resulting three-parameter model (mean, additive, and dominance) was adequate for all $(\mathrm{E} \times \mathrm{I})$ families. A significant additive component was found in all $(\mathrm{E} \times \mathrm{I})$ families. The dominance component was significant in three of the four families.

Broad-sense heritability estimates for plant dry weight were $>60 \%$ in all families (Table 3). Estimates of narrow-sense heritability were $47 \%$ to $49 \%$ and $68 \%$ to $75 \%$, respectively, in two families analyzed (Table 6).

\section{Discussion}

Genetic variation in the efficiency of Ca use by tomato strains was demonstrated. The results obtained from progenies grown
Table 5. Estimates of gene effects in a three-parameter model for total plant dry weight of (E) x (I) families.

\begin{tabular}{ccccc}
\hline \hline Parameter & $113 \times 67$ & $99 \times 118$ & $113 \times 118$ & $99 \times 67$ \\
\hline Mean & $3.663^{* *}$ & $3.101^{* *}$ & $3.895^{* *}$ & $4.135^{* *}$ \\
(SE) & $(0.056)$ & $(0.087)$ & $(0.060)$ & $(0.072)$ \\
Additive & $0.401^{* *}$ & $0.330^{*}$ & $0.587^{* *}$ & $0.382^{* *}$ \\
(SE) & $(0.058)$ & $(0.089)$ & $(0.058)$ & $(0.070)$ \\
Dominance & $0.280^{*}$ & $0.314^{*}$ & $0.634^{* *}$ & 0.049 \\
$(\mathrm{SE})$ & $(0.093)$ & $(0.122)$ & $(0.119)$ & $(0.121)$ \\
$\chi^{\mathbf{2}^{\mathbf{2}}}$ & $7.293^{\mathrm{NS}}$ & $5.451^{\mathrm{NS}}$ & $2.179^{\mathrm{NS}}$ & $6.688^{\mathrm{NS}}$ \\
\hline
\end{tabular}

${ }^{\mathrm{z}} \chi^{2}=$ value from a three-parameter model.

$*, * *$ Significant at $P=0.05$ or 0.01 , respectively.

under low-Ca stress indicated that differences in efficiency were fairly consistent over experiments-strains 99 and 113 were always Ca-efficient and strains 67 and 118 were always Cainefficient. The averages of total plant dry weight produced by efficient strains were $\approx 30 \%$ greater than those produced by inefficient strains. The selection for efficient and inefficient extreme types in the screening phase at low-Ca conditions provided reliable parental strains for genetic study.

The solution culture technique for evaluating the response to low-Ca stress permits response differences to be expressed in only 28 to 30 days. The seedling test for efficiency in Ca use found in tomatoes, therefore, may have wide usage in breeding for tolerance to Ca-related disorders, such as tip burn in cabbage and lettuce, and black heart in celery.

There were no maternal effects on the efficiency of Ca use, confirming the results of Giordano et al. (1982) for tomato strains studied in a somewhat different low-Ca nutrient system.

Previous studies in our laboratory revealed different genetic mechanisms for nutrient use, varying from a single gene for $\mathrm{K}$ 
Table 6. Regression coefficients, narrow-sense heritability $\left(\mathrm{H}_{\mathrm{N}}\right)$ estimates, and the standard errors of the estimates for the families $(99$ $\times 118)$ and $(113 \times 118)$.

\begin{tabular}{|c|c|c|c|c|c|c|c|c|c|}
\hline \multirow[b]{2}{*}{ Family } & \multicolumn{2}{|c|}{$\begin{array}{l}\text { Mean dry wt of } \\
\text { designated parents } \\
\text { (random plants) }\end{array}$} & \multicolumn{2}{|c|}{$\begin{array}{c}\text { Mean dry wt of } \\
\text { progenies derivẹd from } \\
\text { designated parents }\end{array}$} & \multicolumn{2}{|c|}{$\begin{array}{l}\text { Regression of } \\
\text { derived progenies } \\
\text { on their parents }\end{array}$} & \multirow{2}{*}{$\begin{array}{l}\text { Standard } \\
\text { error of } \\
\text { regression }\end{array}$} & \multirow{2}{*}{$\begin{array}{l}\text { Heritability } \\
\text { estimates } \\
(\%)\end{array}$} & \multirow{2}{*}{$\begin{array}{c}\text { Standard } \\
\text { error of } \\
\mathrm{H}_{\mathrm{N}} \text { estimates } \\
\end{array}$} \\
\hline & Source & Dry wt (g) & Source & Dry wt (g) & Source & $\mathrm{RC}^{\mathrm{z}}$ & & & \\
\hline $99(\mathrm{E}) \times 118(\mathrm{I})$ & $\begin{array}{l}\mathrm{F}_{2} \\
\mathrm{BC}_{1} \mathrm{P}_{1} \\
\mathrm{BC}_{1} \mathrm{P}_{2}\end{array}$ & $\begin{array}{l}4.068 \\
4.063 \\
3.950\end{array}$ & $\begin{array}{l}\mathrm{F}_{3} \\
\mathrm{BC}_{1} \mathrm{P}_{1} \mathrm{~S}_{1} \\
\mathrm{BC}_{1} \mathrm{P}_{2} \mathrm{~S}_{1}\end{array}$ & $\begin{array}{l}4.205 \\
4.204 \\
4.085\end{array}$ & $\begin{array}{l}\mathrm{F}_{3}, \mathrm{~F}_{2} \\
\mathrm{BC}_{1} \mathrm{P}_{1} \mathrm{~S}_{1}, \mathrm{BCP}_{1} \\
\mathrm{BC}_{1} \mathrm{P}_{2} \mathrm{~S}_{1}, \mathrm{BCP}_{2}\end{array}$ & $\begin{array}{l}0.74 \\
0.72 \\
0.70\end{array}$ & $\begin{array}{l}0.07 \\
0.26 \\
0.08\end{array}$ & $\begin{array}{l}49 \\
48 \\
47\end{array}$ & $\begin{array}{l}0.05 \\
0.17 \\
0.05\end{array}$ \\
\hline $113(\mathrm{E}) \times 118(\mathrm{I})$ & $\begin{array}{l}\mathrm{F}_{2} \\
\mathrm{BC}_{1} \mathrm{P}_{1} \\
\mathrm{BC}_{1} \mathrm{P}_{2}\end{array}$ & $\begin{array}{l}4.511 \\
4.524 \\
4.155 \\
\end{array}$ & $\begin{array}{l}\mathrm{F}_{3} \\
\mathrm{BC}_{1} \mathrm{P}_{1} \mathrm{~S}_{1} \\
\mathrm{BC}_{1} \mathrm{P}_{2} \mathrm{~S}_{1} \\
\end{array}$ & $\begin{array}{l}4.706 \\
4.685 \\
4.174 \\
\end{array}$ & $\begin{array}{l}\mathrm{F}_{3}, \mathrm{~F}_{2} \\
\dot{\mathrm{BC}}_{1} \mathrm{P}_{1} \mathrm{~S}_{1}, \mathrm{BCP}_{1} \\
\mathrm{BC}_{1} \mathrm{P}_{2} \mathrm{~S}_{1}, \mathrm{BCP}_{2} \\
\end{array}$ & $\begin{array}{l}1.03 \\
1.02 \\
1.13 \\
\end{array}$ & $\begin{array}{l}0.13 \\
0.11 \\
0.15 \\
\end{array}$ & $\begin{array}{l}69 \\
68 \\
75 \\
\end{array}$ & $\begin{array}{l}0.09 \\
0.07 \\
0.10 \\
\end{array}$ \\
\hline
\end{tabular}

${ }^{\mathrm{z}} \mathrm{RC}=$ regression coefficient.

in beans (Shea et al., 1967) to multigenic differences between efficient and inefficient strains for $\mathrm{K}$ in tomatoes (Makmur et al., 1978; Figdore et al., 1989), $\mathrm{N}$ in tomatoes (O'Sullivan et al., 1974), and $P$ in beans (Whiteaker et al., 1976). Our results suggest that relatively few major genes control the efficiency of $\mathrm{Ca}$ use in tomatoes. In all families from $\mathrm{E} \times \mathrm{I}$ parents, additive and dominance gene effects, made significant contributions to the efficiency of Ca use (Table 5). Broad-sense heritability was $>60 \%$ for total plant dry weight. Thus, efficiency of Ca use is a highly heritable trait in tomato.

In our study, narrow-sense heritability $\left(\mathrm{H}_{\mathrm{N}}\right)$ estimates were obtained by using the parent-offspring regression, a method commonly used to estimate narrow-sense heritability of quantitative characters. Smith and Kinman (1965) reported that the regression coefficient estimates of narrow-sense heritability in a self-pollinated population will be biased upward if the inbreeding coefficient of the parent is greater than zero, as with the regression of $\mathrm{F}_{3}$ progeny on $\mathrm{F}_{2}$ parents. They suggested that the correct estimator for the general case is $b /\left(2 r_{\mathrm{XY}}\right)$. Fawole et al. (1982) did not adjust for the previous inbreeding of parents when they regressed offspring on parents, which might explain why the estimates of narrow-sense heritability in some crosses were $>100 \%$ and higher than broad-sense heritability estimates for $\mathrm{P}$ use in the bean strains they studied. In our study, the regression coefficient (B) was very high in all progenies of the family $113(\mathrm{E}) \times 118(1)$, and was relatively high in all progenies of the family $99(\mathrm{E}) \times 118(1)$. To avoid an upward bias, estimates of narrow-sense heritability were calculated using the formula $\mathrm{H}_{\mathrm{N}}=\mathrm{b} / 2 \mathrm{r}_{\mathrm{XY}}$, which provides an adjustment for the known level of inbreeding.

The high and moderately high broad- and narrow-sense heritability values found for total plant dry weight suggested that the heritable differences in Ca efficiency among the tomato strains may warrant the use of these strains, especially strain 113(E), in a tomato breeding program aimed at improved adaptation to low-Ca stress. Some $\mathrm{F}_{3}, \mathrm{BC}_{1} \mathrm{P}_{1} \mathrm{~S}_{1}$, and $\mathrm{BC}_{1} \mathrm{P}_{2} \mathrm{~S}_{1}$ plants had higher dry matter than efficient parent strains 113 and 99 (Li, 1989), suggesting that selection of superior individuals in segregating populations would be successful.

Behling et al. (1989) reported that efficient strain 113 was able to continue growth and metabolism in all parts of the plant under a relatively low percentage of $\mathrm{Ca}$ in its tissue. They also pointed out that the efficiency of $\mathrm{Ca}$ use in strain 113(E) was associated with distribution and translocation of $\mathrm{Ca}$ even in the apparent absence of transpiration. In the present study, all crosses with strain 113(E) had high broad- and narrow-sense heritability values. The crosses with strain $99(\mathrm{E})$ had lower broad- and narrow-sense heritability values than other crosses, suggesting that breeding tomatoes for $\mathrm{Ca}$ efficiency using this strain would probably be more difficult, and the gain from selection would be smaller than from using efficient strain 113. However, strain 99(E) always continued growing until harvest time in every lowCa experiment. Behling (1987) reported that efficient strain 99 removed ions from solution at a different rate than did other strains. The slow removal of ions by strain $99(\mathrm{E})$ appeared to be correlated with its growth pattern. Thus, the character of slow growth rate under low-Ca stress in- strain 99(E) also could be valuable for developing cultivars adapted to low-Ca environmental conditions.

\section{Literature Cited}

Banuelos, G. S., F. Bangerth, and H. Marschner. 1987. Relationship between polar basipetal auxin transport and acropetal $\mathrm{Ca}^{2+}$ transport into tomato fruits. Physiol. Plant. 71:321-327.

Banuelos, G. S., F. Bangerth, and H. Marschner. 1988. Basipetal auxin transport in lettuce and its possible involvement in acropetal calcium transport and incidence of tipburn. J. Plant Nutr. 11(5):525-533.

Behling, J.P. 1987. Variation in Ca distribution and utilization by lines of Lycopersicon esculentum Mill. grown under low-Ca stress. PhD Diss., Univ. of Wisconsin-Madison.

Behling, J. P., W.H. Gabelman, and G.C. Gerloff. 1989. The distribution and utilization of calcium by two tomato (Lycopersicon esculentum[um Mill. ) lines differing in calcium efficiency when grown under low-Ca stress. Plant \& Soil 113: 189-196.

Clarkson, D.T. 1965. Calcium uptake by calcicole and calcifuge species in the genus Agrostis L. J. Ecol. 53:427-435.

Fawole, I, W.H. Gabelman, and G.C. Gerloff. 1982. Heritability of efficiency in phosphorus utilization in beans (Phaseolus vulgaris L.) grown under phosphorus stress. J. Amer. Soc. Hort. Sci. 107(1):94-97.

Figdore, S. S., W.H. Gabelman, and G.C. Gerloff. 1989. Inheritance of potassium efficiency, sodium substitution capacity, and sodium accumulation in tomatoes grown under low-potassium stress. J. Amer. Sot. Hort. Sci. 114(2):322-327.

Giordano, L. B., W.H. Gabelman, and G.C. Gerloff. 1982. Inheritance of differences in calcium utilization by tomatoes under low-calcium stress. J. Amer. Soc. Hort. Sci. 107:664-669.

Hallauer, A.R. and J.B. Miranda. 1981. Quantitative genetics in maize breeding. Iowa State Univ. Press, Ames.

Li, Y. 1989. Inheritance of efficiency in calcium utilization in tomatoes (Lycopersicon esculentum Mill.) grown under low-calcium stress. PhD Diss., Univ. of WisconsinMadison.

Makmur, A., G.C. Gerloff, and W.H. Gabelman 1978. Physiology and inheritance of efficiency in potassium utilization in tomatoes grown under potassium stress. J. Amer. Soc. Hort. Sci. 103(4):545-549.

Marschner, H. 1986. Mineral nutrition of higher plants. Academic, New York.

Mather, K. and J.L. Jinks. 1977. Introduction to biometrical genetics. Cornell Univ. Press, Ithaca, N.Y.

O'Sullivan, J., W.H. Gabelman, and G.C. Gerloff. 1974. Variation in efficiency of nitrogen utilization in tomato (Lycopersicon esculentum Mill.) grown under nitrogen stress. J. Amer. Soc. Hort. Sci. 99:543-547.

Shea, P. F., W.H. Gabelman, and G.C. Gerloff. 1967. The inheritance of efficiency in potassium utilization in snapbeans (Phaseolus vulgaris L.). Proc. Amer. Soc. Hort. Sci. 91:286-293.

Smith, J.D. and M.L. Kinman. 1965. The usc of parent-offspring regression as an estimator of heritability. Crop Sci. 5:595-596.

Voigt, R. L., C.O. Gardner, and O.J. Webster. 1966. Inheritance of seed size in sorghum, Sorghum vulgare Pers. Crop Sci. 6:582-586.

Whiteaker, G., G.C. Gerloff, W.H. Gabelman, and D. Lindgren. 1976. Intraspecific differences in growth of beans at stress levels of phosphorus. J. Amer. Soc. Hort. Sci. 101:472-475. 